\title{
Wood Ash in Canavalia ensiformis L. Cultivation on Highly Weathered Soil in Brazil
}

\author{
Edna Maria Bonfim-Silva ${ }^{1 *}$, Marcel Thomas Job Pereira ${ }^{1}$, \\ Julyane Vieira Fontenelli ${ }^{1}$, Janaína M. Gonçalves Carvalho ${ }^{1}$, \\ Alessana Franciele Schlichting ${ }^{1}$ and Tonny José Araújo da Silva ${ }^{1}$ \\ ${ }^{1}$ Department of Agricultural and Environmental Engineering, Institute of Agricultural Sciences and \\ Technology, Federal University of Mato Grosso, Rondonópolis, Brazil.
}

\begin{abstract}
Authors' contributions
This work was carried out in collaboration between all authors. The authors EMBS and TJAS conceived the idea, designed the experiment and edited the manuscript. The authors MTJP, JVF and JMGC conducted the experiment, statistical data analysis, interpretation of results and preparation of first draft of the manuscript. The author AFS interpretation of results and edited the manuscript. All authors read and approved the final manuscript.

Article Information

DOI: $10.9734 /$ IJPSS/2017/34097

Editor(s):

(1) Prof. Marco Trevisan, Institute of Agricultural Chemistry and Environmental Research Centre BIOMASS, Faculty of Agriculture, Catholic University of the Sacred Heart, Italy. Reviewers:

(1) Benjamin A. Osei, University of Cape Coast, Ghana. (2) Rahim Foroughbakhch, University of Nuevo Leon, Mexico. Complete Peer review History: http://www.sciencedomain.org/review-history/19606
\end{abstract}

Original Research Article

Received $12^{\text {th }}$ May 2017

Accepted $10^{\text {th }}$ June 2017

Published $19^{\text {th }}$ June 2017

\begin{abstract}
The aim of study was to avaliate the productive and structural features of Canavalia ensiformis L. resulting from the wood ash acting as a soil corrective and fertilizer in the Oxisol. The experiment was performed in a greenhouse, from April to July 2012, in the Municipality of Rondonópolis, State of Mato Grosso, Brazil. The experiment, with Oxisol, use as of six wood ash doses $(0.0,3.0,6.0$, 9.0, 12.0 and $15.0 \mathrm{~g} \mathrm{dm}^{-3}$ ). Harvesting of the Canavalia ensiformis L. was done 60 days post germination, in plastic pots of $4 \mathrm{dm}^{-3}$ capacity, to which the wood ash doses had been administered 20 days prior to planting. At the time of flowering, the following measurements were recorded, plant height, indirect chlorophyll index of leaf, stem diameter, leaf number count, soil pH, dry mass of shoot, dry mass of root, numbers and dry mass of the Rhizobia-rich root nodules. The findings were then submitted to the analysis of variance and regression test, up to $p=0.05$ significance. The wood ash acted as a corrective and induced a pH increase, enhancing the soil chemistry. Influencing the
\end{abstract}


number of leaves, dry mass of leaves and nodules. The other variables analyzed, which were adjusted to the quadratic regression model, demonstrated improved results when 9 to $12 \mathrm{~g} \mathrm{dm}^{-3} \mathrm{of}$ wood ash per pot were added.

Keywords: Cover crop; soil correction; vegetal residue.

\section{INTRODUCTION}

Responsibility for the environment and energy insecurity have kindled a great need for alternative renewable energy resources, among which biomass burning (trunks, forest and agricultural residues) used in power plants ranks high as an economically viable energy source [1], and which generates wood ash.

The burning of waste wood in the process of power production produces wood ash as an industrial residue. Wood ash has been found to be a viable alternative in agricultural soils as it contains substantial quantities of plant nutrients. Wood ash thus becomes a good source of essential plant nutrients like $\mathrm{Ca}, \mathrm{K}, \mathrm{Mg}$ and $\mathrm{P}$ [2] and exerts a corrective influence on acidic soils [3].

The predominant requirements for crop cultivation in acidic soils include soil correction and macronutrient availability, particularly with reference to the first crop. The soil acidity as one of the principal limiting factors for agricultural production [4]. South America hosts roughly $1,180.3 \times 106$ ha of acidic soils. As nitrogen occurs only in traces in wood ash, it must necessarily be added to the system, in a more sustainable manner, by incorporating green manure into the soil during crop cultivation.

Green manure added to the soil gets incorporated and decomposed, and mineralization and nitrification occur with the release of nitrogen (mineral; $\mathrm{NH}_{4}-\mathrm{N} ; \mathrm{NO}_{3}-\mathrm{N}$ ) for the next crop [5]. The $\mathrm{C} / \mathrm{N}$ ratio of the green manure is a reflection of its worth as a nitrogen fertilizer [6]. When the green manure shows a C / $\mathrm{N}$ ratio of 8 it implies a high soil nitrogen mineralization; however, when the $\mathrm{C} / \mathrm{N}$ ratio equals 12 , it reflects the value of the Francosandy loam and loamy clay soils [5]. The C / N ratio of 14.9 for Jack bean (Canavalia ensiformis L.), which when used as green manure, affected the soil microbial action and soil nitrogen availability [7].

The need to identify alternatives for wood ash disposal was high, the aim of study was to avaliate the productive and structural features of Canavalia ensiformis L. resulting from the wood ash acting as a soil corrective and fertilizer in the Oxisol.

\section{MATERIALS AND METHODS}

The experiment was performed in a greenhouse in the Municipality of Rondonópolis, State of Mato Grosso, Brazil, at the co-ordinates of $16^{\circ}$ $28^{\prime} 15^{\prime}$ 'S and $54^{\circ} 38^{\prime} 05$ ", at an altitude of 227 $\mathrm{m}$. The region displayed the Aw climate pattern according to the Köppen classification, with $27^{\circ} \mathrm{C}$ average temperature and $62 \%$ mean humidity, as maintained in the greenhouse during the experiment.

The completely randomized experimental design was used, the wood ash was applied at rate of $0.0,3.0,6.0,9.0,12.0$ and $15.0 \mathrm{~g} \mathrm{dm}^{-3}$, and six replications in total, amounting to a total of 36 experimental units.

The experimental units involved plastic containers of $4 \mathrm{dm}^{-3}$ soil capacity. The Dystrophic Oxisol (Table 1) taken from the region of the first crop was used. It had been collected prior from the $0-20 \mathrm{~cm}$ soil layer and sieved through a 2 $\mathrm{mm}$ mesh. The wood ash (Table 2) applied was taken from the burning of the Eucalyptus sp. used in the energy generation of the industries in that area.

Table 1. Chemical and granulometric characteristics of the Oxisol in the $\mathbf{0 - 2 0} \mathrm{cm}$ depth

\begin{tabular}{|c|c|c|c|c|c|c|c|c|c|c|c|}
\hline $\mathrm{pH}$ & $\mathbf{P}$ & $\mathrm{Ca}$ & Mg & $\mathbf{H}$ & $\mathrm{Al}$ & SB & CTC & $\mathbf{V}$ & O.M. & Sand & Clay \\
\hline$\left(\mathrm{CaCl}_{2}\right)$ & $-\left(\mathrm{mg} \mathrm{dm}^{-3}\right)-$ & ---- & ----( & imol & $\left.\mathrm{dm}^{-3}\right)$ & ------. & ----" & $(\%)$ & $\left(\mathrm{g} \mathrm{dm}^{-3}\right)$ & -----(g kg & ------- \\
\hline 4.1 & 2.4 & 0.3 & 0.2 & 4.2 & 1.1 & 0.6 & 5.9 & 9.8 & 22.7 & 549 & 367 \\
\hline
\end{tabular}


Table 2. Chemical composition of wood ash

\begin{tabular}{lccccccccc}
\hline $\mathbf{p H}$ & $\mathbf{P}_{\mathbf{2}} \mathbf{O}_{5}$ & $\mathbf{K}_{\mathbf{2}} \mathbf{O}$ & $\mathbf{C a}$ & $\mathbf{M g}$ & $\mathbf{S}$ & $\mathbf{B}$ & $\mathbf{F e}$ & $\mathbf{M n}$ & $\mathbf{Z n}$ \\
\hline$\left(\mathrm{CaCl}_{2}\right)$ & --88 & 4.00 & 2.31 & 1.22 & 0.26 & 0.02 & 2.52 & 0.03 & 0.01 \\
\hline 10.4 & 2.88 & & & & & & & &
\end{tabular}

The wood ash was mixed with the soil and incubated for 30 days. The soil was watered and the moisture content was kept at $60 \%$ of the maximum water retention capacity. Measurements were taken every day using the gravimetric method [8]. After the incubation period five seeds Canavalia ensiformis L. was sown in the pot at $0.025 \mathrm{~m}$ depth. On the 10th days after planting only one plant per experimental unit was left.

Cultivation of the Canavalia ensiformis L. plant until it flowered (at 60 days post germination). At this point in time, the following parameters were determined: indirect chlorophyll index, soil $\mathrm{pH}$, plant height, leaf number, stem diameter and the dry mass of shoot, root and nodules. The plant height was measured from the ground level to the point of insertion of the last leaf. Using calipers, the stem diameter was measured at 1 $\mathrm{cm}$ from the ground level. Indirect evaluation of the chlorophyll index in the leaves and the Falker indices were confirmed using the ClorofiLOG model CFL 1030 apparatus. Using $0.01 \mathrm{M} \mathrm{CaCl}_{2}$ solution in $10 \mathrm{~cm}^{3}$ of soil, the $\mathrm{pH}$ was calculated.

Once the measurements were recorded, cutting of the plants was done at the ground level and the dry mass of the aerial plant parts determined; the roots were then washed and their dry mass was assessed. The root nodules (Rhizobia) present in the plant roots were counted and their dry mass was recorded. The material was placed in an oven under forced air circulation at $\pm 65^{\circ} \mathrm{C}$ until constant mass was attained and after weighing in an analytical balance, the dry mass was determined.

The findings were submitted to the analysis of variance and regression test, up to $\mathrm{p}=.05$ probability. Employing the SISVAR statistical program [9].

\section{RESULTS AND DISCUSSION}

The indirect chlorophyll index in the leaf, the Falker index, revealed its highest value (51) for the wood ash dose of $9.53 \mathrm{~g} \mathrm{dm}^{-3}$, demonstrating that the plant nutrition, with respect to the nitrogen absorption, was greater at that dose (Fig. 1). The best nutrition for the Jack bean was at 60 days after planting, when the SPAD index, taken on the Minolta apparatus, registered a value of $55[10]$.

The Falker index directly correlates with the nitrogen content in the leaf $(r=0.843)$, at a value of 51 , and roughly indicates a $50 \mathrm{~g} \mathrm{~kg}^{-1}$ nitrogen content in the leaf [11]. It is noteworthy that the nitrogen nutrition in the Jack bean under these experimental conditions was possible essentially through the biological fixation of nitrogen because there was no provision of a nitrogen source.

The soil $\mathrm{pH}$ revealed statistical differences 60 days post wood ash application, the highest value ( $\mathrm{pH} 5.38)$ reached in the dose of wood ash of $13.90 \mathrm{~g} \mathrm{dm}^{-3}$ (Fig. 2). The wood ash used signifies the calcium, potassium and phosphorus levels, so that the $\mathrm{pH}$ rise can be ascribed largely to the release of calcium and potassium carbonates present in the soil, through the application of the wood ash. The escalation in the soil pH post ash application [12].

It occurred in the soil $\mathrm{pH}$ due to the application of up to $12 \mathrm{t} \mathrm{ha}^{-1}$ of wood ash; the application of 10 $\mathrm{t} \mathrm{ha}^{-1}$ of wood ash caused the $\mathrm{pH}$ to rise to 7.6, whereas in the treatment lacking the addition of the vegetable ash, the $\mathrm{pH}$ remained at 6.4 [13].

With respect to the plant height the bean showed (Fig. 3) that the wood ash dose of $10.72 \mathrm{~g} \mathrm{dm}^{-3}$ induced the greatest height $(61.36 \mathrm{~cm})$. This increase was most likely the effect of the wood ash which had enriched the soil and enhanced its chemical properties [14,15]. Besides, the utilization of organic fertilizers like plant ash can aid in optimizing the plant growth, thereby minimizing the production costs [16].

With reference to the number of leaves, an increase of $51.63 \%$ compared with the control was recorded in response to the higher dose of wood ash applied (Fig. 4). This rise may be attributed to the nutrients that constitute the wood ash (Table 2), which induced the increase in leaf number.

The highest production in the Crotalaria juncea crop, (an increase of $62.52 \%$ when compared 
with the control) occurred in response to the application of wood ash dose of $10.99 \mathrm{~g} \mathrm{dm}^{-3}$ [17]. Thus, it is evident that the wood ash enhances plant development because leaf expansion is an accurate indicator for the estimation of the vegetative growth in legumes.

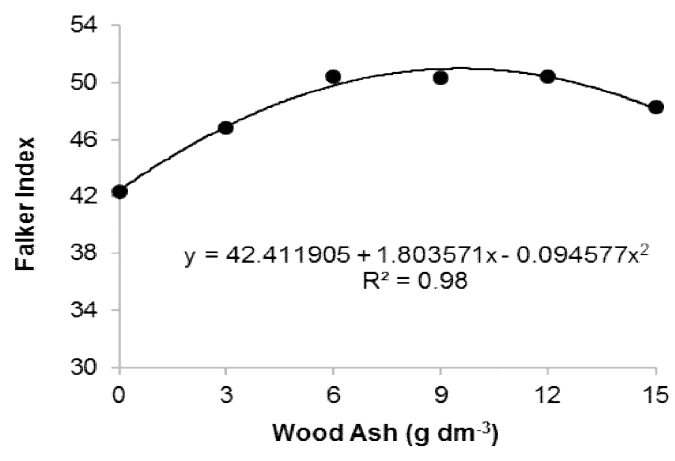

Fig. 1. Falker Index in Canavalia ensiformis L. as function of plant wood ash doses

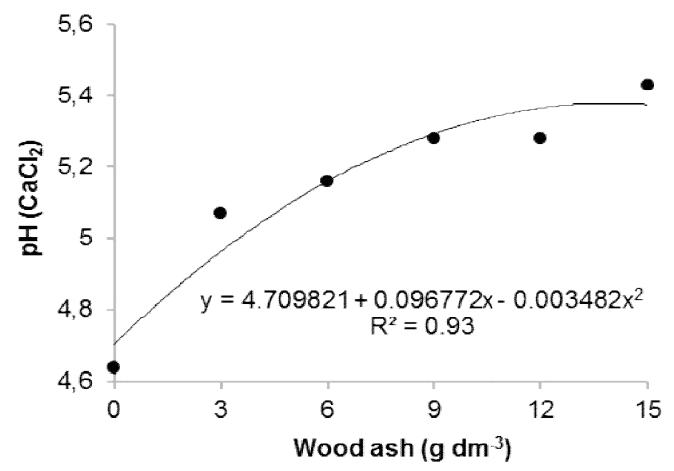

Fig. 2. Soil pH of the soil as function of plant wood ash doses

The wood ash application also influenced stem diameter, with the largest stem diameter (5.48 $\mathrm{cm}$ ) recommended by the application of the $10.97 \mathrm{~g} \mathrm{dm}^{-3}$ (Fig. 5). The wood ash supplements when added to the soil produced increased stem diameter in Crotalaria juncea [18]. Plants possessing larger stem diameter show improved balance in shoot growth [18].

The maximum yield $(26.93 \mathrm{~g})$ of dry mass of the shoot was recorded for the wood ash dose of $11.94 \mathrm{~g} \mathrm{dm}^{-3}$, registering a increase of $66.06 \%$ in comparison with the control (Fig. 6). The applied ash conditioned the soil, which, in turn, stimulated the development of the plant.

In their study on the biomass production of Jack bean (Canavalia ensiformis L.), during the reforestation conduced in the State of Pará,
Brazil, the addition of the dry plant material of Jack bean revealed a high nutrient cycling potential in the soil [19].

On assessing the root dry mass, the wood ash doses were found to induce a substantial rise in the yield of the dry mass of the roots, the highest output being observed for the wood ash dose of $9.2 \mathrm{~g} \mathrm{dm}^{-3}$, demonstrating an increase of $54.5 \%$ hen compared with the control treatment (Fig. 7).

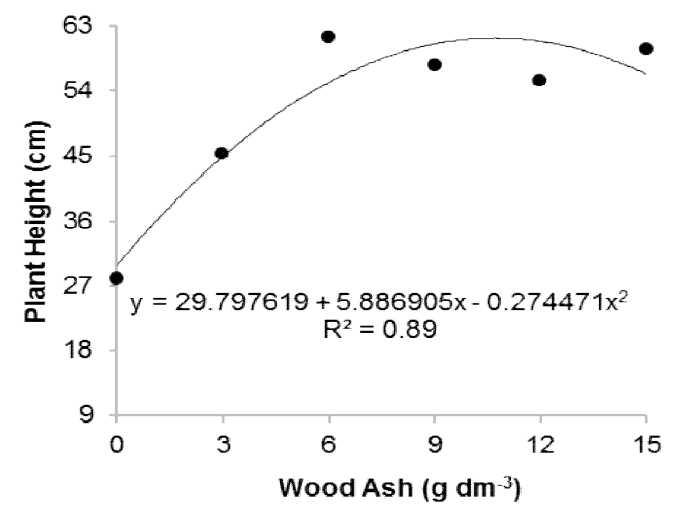

Fig. 3. Height of the Canavalia ensiformis L. plants as function of plant wood ash doses

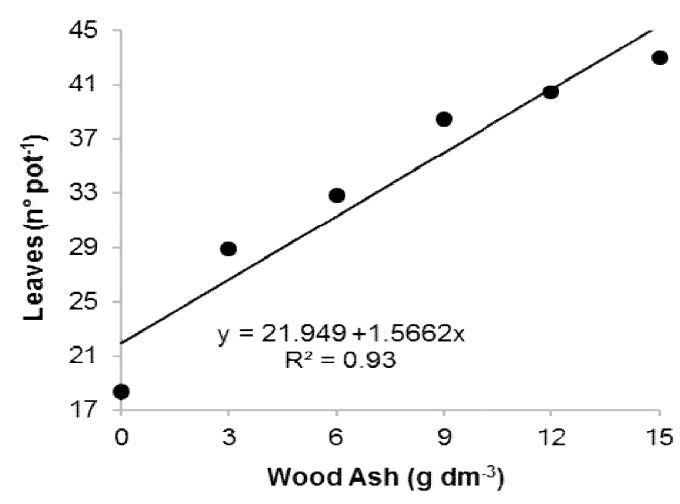

Fig. 4. Number of Canavalia ensiformis L. pot as function of plant wood ash doses

The ash could ensure a good supply of $\mathrm{Ca}$ and $\mathrm{Mg}$, as well as decrease the $\mathrm{Al}$ content present in the soil, thus minimizing the toxicity and raising the concentration of nutrients available to the plants [20].

The wood ash doses were noted to influence the number and dry mass of the nodules (Fig. 8A and $8 \mathrm{~B})$. The wood ash applied induced the increase of 64.33 and $93.24 \%$ in the number and dry mass of the nodules, respectively, in the final dose supplied when compared with the control. 
As the wood ash used contains high phosphorus concentrations (Table 2), it influences the nitrogenase enzyme activity due to the highenergy expenditure, stimulated by the natural biological nitrogen fixation that occurs in legumes.

The application of up to $8 \mathrm{tha}^{-1}$ the wood ash in the forest, reported no influence of the addition of the ash on the total microbial biomass in the mineral and organic soil layers. While the authors suggested that the low dose exerts some effect, the temperature, which hovered between 14.5 and $-19.0^{\circ} \mathrm{C}$ during the course of the experiment, may have also affected this finding [21].

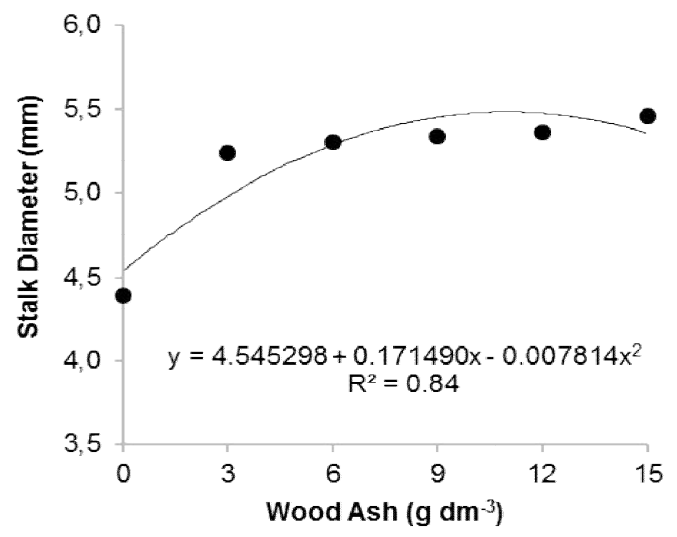

Fig. 5. Stem diameter of Canavalia ensiformis L. plants as function of plant wood ash doses

Occurs a linear rise in nodule production resulting from the increasing doses of the phosphorus added in Trifolium subterraneum L. cv. Woogenellup. Therefore, the ash used was

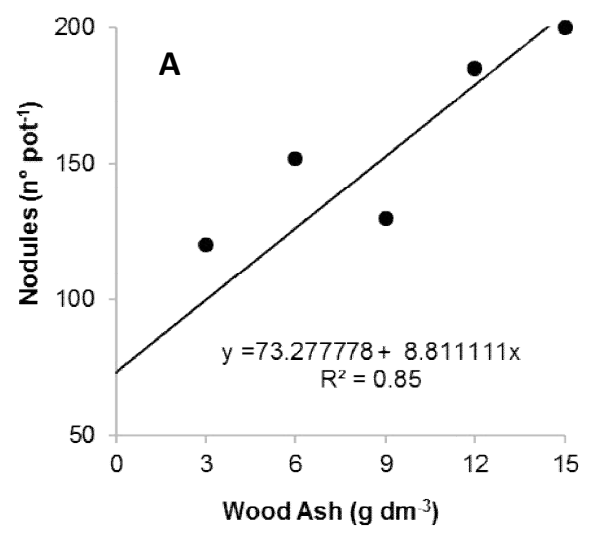

seen to increase the number and the dry mass of the nodules in the bean cultivated [22].

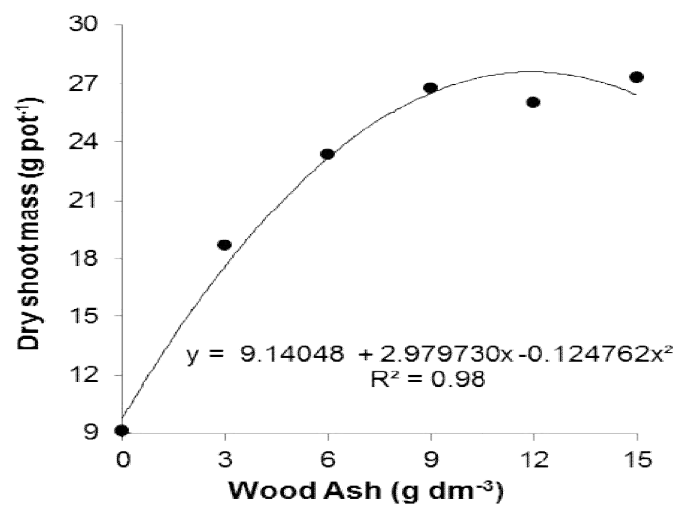

Fig. 6. Dry mass of the aerial part of Canavalia ensiformis $L$. as function of plant wood ash doses

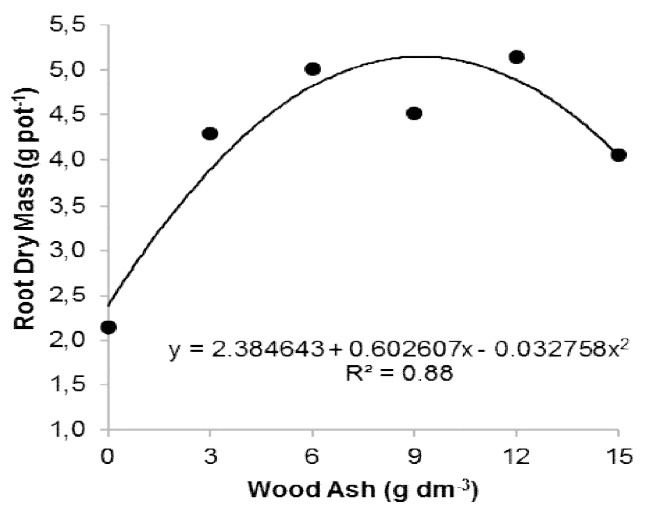

Fig. 7. Dry root mass of the Canavalia ensiformis L. as function of plant wood ash doses

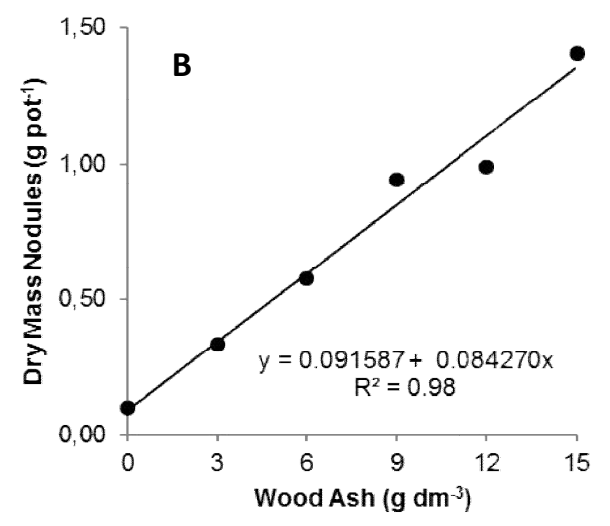

Fig. 8. Number of nodules (A) and dry mass of nodules (B) of Canavalia ensiformis L. as function of plant wood ash doses 
The Canavalia ensiformis L. revealed the best chemical quality of the residue, showing higher $\mathrm{N}, \mathrm{P}$ and $\mathrm{Ca}$ residues, which are essential for green manuring [23].

\section{CONCLUSION}

The wood ash increases the $\mathrm{pH}$ of the soil improving the chemical quality of the soil. Wood ash effective alternatives like soil correction and fertilizers especially for the first culture of Canavalia ensiformis L.

The vegetal ash added in a $15 \mathrm{~g} \mathrm{dm}^{-3}$ dose increases the production of the greatest number of leaves and nodules, as well as dry mass of the nodules. The indirect chlorophyll index, plant height, soil $\mathrm{pH}$ and stem diameter revealed the best results when 9 to $12 \mathrm{~g} \mathrm{dm}^{-3}$ doses of wood ash were used.

\section{ACKNOWLEDGEMENTS}

The Water and Soil Practices Group of the Federal University of Mato Grosso, Campus de Rondonópolis, for all the assistance provided.

\section{COMPETING INTERESTS}

Authors have declared that no competing interests exist.

\section{REFERENCES}

1. Chowdhury S, Mishra M, Suganya O. The incorporation of wood waste ash as a partial cement replacement material for making structural grade concrete: An overview. Ain Shams Engineering Journal. 2015;6:429-437.

Available:http://dx.doi.org/10.1016/j.asej.20 14.11.005

2. Etitgni L, Campbell AG. Physical and chemical characteristics of wood ash. Bioresource Technology. 1991;37:173178.

3. Saarsalmi A, Smolander A, Kukkola M, Arola M. Effect of wood ash and nitrogen fertlization on soil chemical properties, soil microbial processes, and stand growth in two coniferous stands in Finland. Plant Soil. 2010;331:329-340.

4. Fageria NK, Stone LF. Management of the acidity of cerrado and várzea soils of Brazil. Santo Antônio de Goiás: Embrapa Rice and Beans. 1999;Documents 92:42. English
5. Castro LL, Whalen JK. Ion exchange membranes are sensitive indicators of ammonium and nitrate released from green manures with low $\mathrm{C} / \mathrm{N}$ ratios. European Journal of Soil Biology. 2016; 77:4-8.

Available:http://dx.doi.org/10.1016/i.ejsobi. 2016.09.001

6. Diallo M, Duponnois $R$, Guisse A, Sall $S$, Chotte JL, Thioulouse J. Biological effects of native and exotic plant residues on plant growth, microbial biomass and $\mathrm{N}$ availability under controlled conditions. Eur. J. Soil Biol. 2006;42:238-246.

7. Collier LS, Correia MAR, Ramos LN, Prado RM, Flores RA, Nunes TV. Phosphate fertilization in the furrow and in bands under legume straw and corn yield in no Tocantins in Tocantins. Ceres Journal. 2008;55(2):109-116. Portuguese

8. Bonfim-Silva EM, Kroth BE, Silva TJA, Koetz M. Initial development of PinhãoManso under soil water availability. Irriga. 2015;20(1):73-81. English.

Available:Http://dx.doi.org/10.15809/irriga. 2015v20n1p73

9. Ferreira DF. SISVAR: A computer statistical analysis system. Science and Agrotechnology. 2011;35(6):1039-1042.

10. Paludo JTS, Bonfim-Silva EM, Silva TJA, Vila TA. Soil compaction: SPAD index AND number of leaves of the bean. XLIII Brazilian Congress of Agricultural Engineering - CONBEA 2014 Convention Center "Architect Rubens Gil de Camillo" Campo Grande -MEM 27 to 31 July 2014. 2014;1-4. English.

11. Schlichting AF, Bonfim-Silva EM, Silva MC, Pietro-Souza W, Silva TJA, Farias LN. Efficiency of portable chlorophyll meters in assessing the nutritional status of wheat plants. Brazilian Journal of Agricultural and Environmental Engineering. 2015;19(12): 1148-1151.

Available:Http://dx.doi.org/10.1590/18071929/agriambi.v19n12p1148-1151

12. Omil B, Piñeiro $\mathrm{V}$, Merino $A$. Soil and tree responses to the application of wood ash containing charcoal in two soils with contrasting properties. For. Ecol. Manage. 2013;295:199-212.

Available:http://dx.doi.org/10.1016/j.foreco. 2013.01.024

13. Füzesi I, Heil B, Kovács G. Effects of Wood Ash on the chemical properties of 
soil and crop vitality in small plot experiments. Acta Silv. Lign. 2015;11(1): 55-64.

Available:http://dx.doi.org/10.1515/aslh2015-0004

14. Mandre M. Influence of wood ash on soil chemical composition and biochemical parameters of young Scots pine. Proc. Estonian Acad. Sci. Biol. Ecol. 2006;55(2): 91-107.

15. Bezerra MDL, Bonfim-Silva EM, Silva TJA. Wood ash on the productive characteristics of Marandu grass in Cerrado soils. African Journal of Agricultural Research. 2014;9(30): 23339-2344.

Available:http://dx.doi.org/10.5897/AJAR20 14.8841

16. Lopes FFM, Lima RLS, Albuquerque RC, Silva MIL, Beltrão NEM. Fertilizer use of vegetal ash and sewage sludge for the production of cotton 'cv. ruby'. Part 1. growth variables. In: BRAZILIAN COTTON CONGRESS, 5, 2005, Salvador. Anais ... Salvador: Embrapa CNPA. CD-ROM.2005. English.

17. Bonfim-Silva EM, Silva TJA, Guimarães SLC, Polizel AC. Development and production of Crotalaria juncea fertilized with vegetal ash. Encyclopedia Biosphere. 2011;7(12):1-10.

18. Sheep JGA. Production and quality control of forest seedlings. Curitiba: UFPR / FUPEF, Campos: UENF. 1995;451. English.
19. RayoL BPR, Rayol-Alvino FO. Biomass production and nutrient content of the bean (Canavalia ensiformis (L.) Dc.) In reforestation in the State of Pará. Agroecosystems. 2012;4(2):85-90.

20. Maeda S, Silva HD, Bellote A FJ, Santana DLQ, Saldanha IAA, Dedecek RA, Lima EA. Forest Biomass Ash as an Input for Planting Pinus taeda in Cambisols and Latossolo in Vargem Bonita, SC. Brazilian Agricultural Research Corporation Embrapa. Technical Communication. 2007;187. English

21. Noyce GL, Fulthorpe R, Gorgolewski A, Hazlett P, Tran H, Basiliko N. Soil microbial responses to wood ash addition and Forest fire in managed Ontario forests. Applied Soil Ecology. 2016;107:368-380. Available:http://dx.doi.org/10.1016/j.apsoil. 2016.07.006

22. Krolow RH, Blend C, Rabbit RW, Siewerdt L, Zonta EP. Effect of phosphorus and potassium on the development and nodulation of three annual cold season legumes. Revista Brasileira de Zootecnia. 2004;33(6):2224-2230. English

23. Gama-Rodrigues AC, Gama-Rodrigues EF, Brito EC. Decomposition and nutrient release of cultural residues from hedge plants in Red-yellow Argissolo in the northwest region of Rio de Janeiro. Brazilian Journal of Soil Science. 2007;31: 1421-1428. English

(c) 2017 Bonfim-Silva et al.; This is an Open Access article distributed under the terms of the Creative Commons Attribution License (http://creativecommons.org/licenses/by/4.0), which permits unrestricted use, distribution, and reproduction in any medium, provided the original work is properly cited.

Peer-review history:

The peer review history for this paper can be accessed here: http://sciencedomain.org/review-history/19606 